\title{
Retracted: Ginseng on Hyperglycemia: Effects and Mechanisms
}

\author{
Evidence-Based Complementary and Alternative Medicine
}

Received 24 August 2020; Accepted 14 October 2020; Published 24 November 2020

Copyright (c) 2020 Evidence-Based Complementary and Alternative Medicine. This is an open access article distributed under the Creative Commons Attribution License, which permits unrestricted use, distribution, and reproduction in any medium, provided the original work is properly cited.

Evidence-Based Complementary and Alternative Medicine has retracted the article titled "Ginseng on Hyperglycemia: Effects and Mechanisms" [1], this article has been retracted as it is essentially identical in content with a previously published paper:

$\mathrm{Wu} \mathrm{Z}$, Luo JZ, Luo L. "American ginseng modulates pancreatic beta cell activities." Chin Med. 2007 Oct 25; 2:11.

\section{References}

[1] J. Z. Luo and L. Luo, "Ginseng on Hyperglycemia: Effects and Mechanisms," Evidence-Based Complementary and Alternative Medicine, vol. 6, no. 4, Article ID 632954, 427 pages, 2009. 